Journal of

International Logistics and Trade

\title{
Study on the Optimal Number of Creditors in Shipping Finance Syndication
}

\author{
Min-Hwan Lee, Jae-Joon Han* \\ Division of Global Finance and Banking, Inha University, Incheon, Korea
}

\section{ARTICLE INFO}

Article history:

Received 8 November 2016

Accepted 12 December 2016

Keywords:

Number of creditors

Monitoring

Non-verifiable income

Coordination failure

\begin{abstract}
The restructuring of shipping and shipbuilding companies in the midst of rapidly shrinking global shipping demand has become a prominent issue in Korea. In shipping finance, loan syndication featuring many creditors surges as the preferred option. However, increasing the numbers of creditors in the syndicate results in two opposite effects. First is the beneficial effect from their enhanced monitoring power. On the other hand, there is the adverse effect resulting from increased difficulty in coordination when syndicate members increase, particularly in bankruptcy. Our aim of this paper is to analyze the role of finance in the shipping and shipbuilder markets, and determine the theoretical optimal number of creditors for the shipping finance syndicate based on Bolton and Scharfstein (1996). The two issues above result from moral hazard and non-verifiability: coordination among many creditors for collection of bonds in case of default, and the enhancement of monitoring private benefit exploitation by the ship-owner during default. Considering the two conflicting forces result from an increase in creditor membership, we draw conclusions on determining the optimal number of creditors by considering trade-offs between these two factors: More creditors are preferred when the monitoring effect dominates. Otherwise, less creditors are preferred.
\end{abstract}

\section{Introduction}

Due to the world financial crisis, the size of the global shipping market has been significantly reduced. Shipping demand has drastically declined, particularly freight charges for shipping. In the aftermath, the Korean shipping industry, which have been one of the influential players in the global logistics market, is now under restructure. The top domestic shipping company, Hanjin Shipping Co., Ltd., has filed for legal management. The second largest shipping company, Hyundai Merchant Marine (HMM), also announced that HMM's creditor group has agreed on the company's debt restructuring on the condition that HMM successfully conclude its negotiations with bond holders and ship-owners. On the other hand, the rapid reduction in shipping demand and its earnings deterioration led to a decrease in orders for the shipbuilding industry.

Many reasons have been suggested for the troubled shipbuilding industry, including excessive investment, and falling freight charges in conjunction with the cost burden of expensive ship chartering contracts. However, a fundamental reason lies in the debt burden resulting from Korean companies' high debt ratio relative to global competitors. The problem of high debt ratio applies to the shipbuilding industry as well. Though only 7 Korean shipbuilders had sales volume in excess of 50 billion won in 2014, their total debt was 35.5 trillion won. Their average debt ratio reached $411 \%$ in 2014, significantly higher than the global industry average of $135 \%$. This explains investor and creditor concerns about the worsening performance amid falling new orders in the Korea shipping and shipbuilding industries.

\footnotetext{
* Corresponding author: Division of Global Finance and Banking, Inha University, 100 Inha-ro, Nam-gu, Incheon, 22212, Korea Email: jjhan@inha.ac.kr
} 
Thus, restructuring the heavily indebted shipping and shipbuilding companies has spurred prominent debate in Korea. Since the beginning of 2016, the Deputy Prime Minister of the Economy stated that he cannot further postpone the restructuring of vulnerable enterprises suffering from oversupply, and urged the CEOs of major domestic banks to cooperate with government initiatives. International financial institutions have also offered recommendations. IMF advised that if government desired effective fiscal policy, structural reform is required. Also, Moody's warned that the government's delay in restructuring could have a negative impact on Korea's sovereign credit rating. Thus, restructuring the shipbuilding and shipping sectors is a top economic priority.

While the shipbuilding industry continues to deny speculation over bankruptcy, all three of Korea's biggest shipbuilders, Hyundai Heavy Industries, Samsung Heavy Industries and Daewoo Shipbuilding, have announced restructuring schemes. Daewoo Shipbuilding, which is the most distressed, proposed massive cuts to workforce and wages under pressure from its creditors, as well as temporary dock closures. The national financial supervisory body has stressed the necessity for capital expansion from financial institutions, pressuring the financial industry to provide additional appropriation funds to cope with fulfilling Basel III BIS equity ratio requirements for the shipbuilding industry. The reason why the financial supervisory body intervenes is due to the extent of capital used in the shipbuilding industry, and the adverse effects on the financial system resulting from potential bankruptcy. The funding magnitude created by potential crises exceeds the resources available of any one financial institution ${ }^{\mathrm{a}}$. Therefore, multiple financial institutions provide syndicated loans.

The shipbuilding industry has distinct characteristics resulting in financing schemes that differ from other asset-based industries ${ }^{\mathrm{b}}$. The revenue flows of the shipbuilding industry are highly volatile, as are asset values of ships. These characteristics create challenges for funding decisions by potential lenders and investors. As a result, ship finance is generally regarded as a specialist business; for example, the rating agency Moody's classifies it as 'exotic' finance. Syndicated loans surge as the only viable and preferred option. Also the number of participating members in the syndicate increases. However, increasing the numbers of creditors results in two opposite effects. First, there is a beneficial effect from enhanced monitoring of business operations. It has become the norm to include established financial institutions (or government-run banks) to raise the possibility of collection in bankruptcy. Second, there is the adverse effect from increased difficulty in coordination when syndicate members increase. Coordination is indispensable among the members in both ex-ante and ex-post periods. However, deriving consensus from syndicate members is challenging from initial support decisions to renegotiation in the process of restructuring. It includes whether to extend additional loan, determination of loan amounts, and whether to liquidate loan provisions. With many creditor banks involved, there is the possibility that the negotiation process fails rather than reaches agreement, and the remaining assets not effectively distributed.

The aim of this paper is to explain the role of finance in shipbuilding and shipping industries, and determine the optimal number of creditors for the shipping finance syndication. The rest of the paper is organized as follows: In section 2, we explain ship financing, identify characteristics of ship financing, and explain the current status of ship financing in Korea as well as abroad. In section 3, we analyze the optimal number of creditors for ship finance syndication from the view of incomplete contract as well as summarizing related studies. We view the ship-owner who applies for ship financing as the agent, and banks who participate in syndicate loans are the principals. Two issues arise besides moral hazard and non-verifiability in traditional incomplete contract theory. First is the issue of adjustment of interests among many of the creditors for the debt collection in case of default. It is so because, the greater the number of creditors, the more difficult it is to reach consensus among the members. Second issues concern enhancing monitoring power on private benefit exploitation by ship-owners. It is well established that the greater number of creditors leads to bigger advantage in preventing the private benefits accruing to ship-owners. Considering the two countervailing forces from increased creditor membership, the crucial decision is how to better monitor coordination failure, in conjunction with minimizing inefficiency, in bankruptcy. Finally, section 4 concludes the paper.

\section{An overview of shipping finance}

Shipping finance is a funding method based on the streams of future cash flow resulting from the acquisition, construction, and operation of ships. In general, shipping finance is used by shipping companies to acquire ships, and also by shipbuilders in the process of shipbuilding. As mentioned, ships are very expensive. Therefore, it is difficult for shipbuilding and shipping companies to purchase ships using only their own capital. Shipping finance is integral to both purchasing and building ships. Therefore, shipping finance includes shipping companies, shipbuilders, and financial institutions that fund both industries.

\footnotetext{
${ }^{\text {a }}$ Container-ships and tankers can cost up to $\$ 150$ million each, about the same size as a jumbo jet, while LNG tankers, the most expensive ships, cost twice of those. As ships grew in size during the second half of 20th century, decisions about their funding become the most important ones that shipping companies make.

b As the ships are internationally mobile and their owners can choose their legal jurisdiction, shipping companies are able to adopt less formal corporate structures than other businesses employing such large amounts of capital.
} 


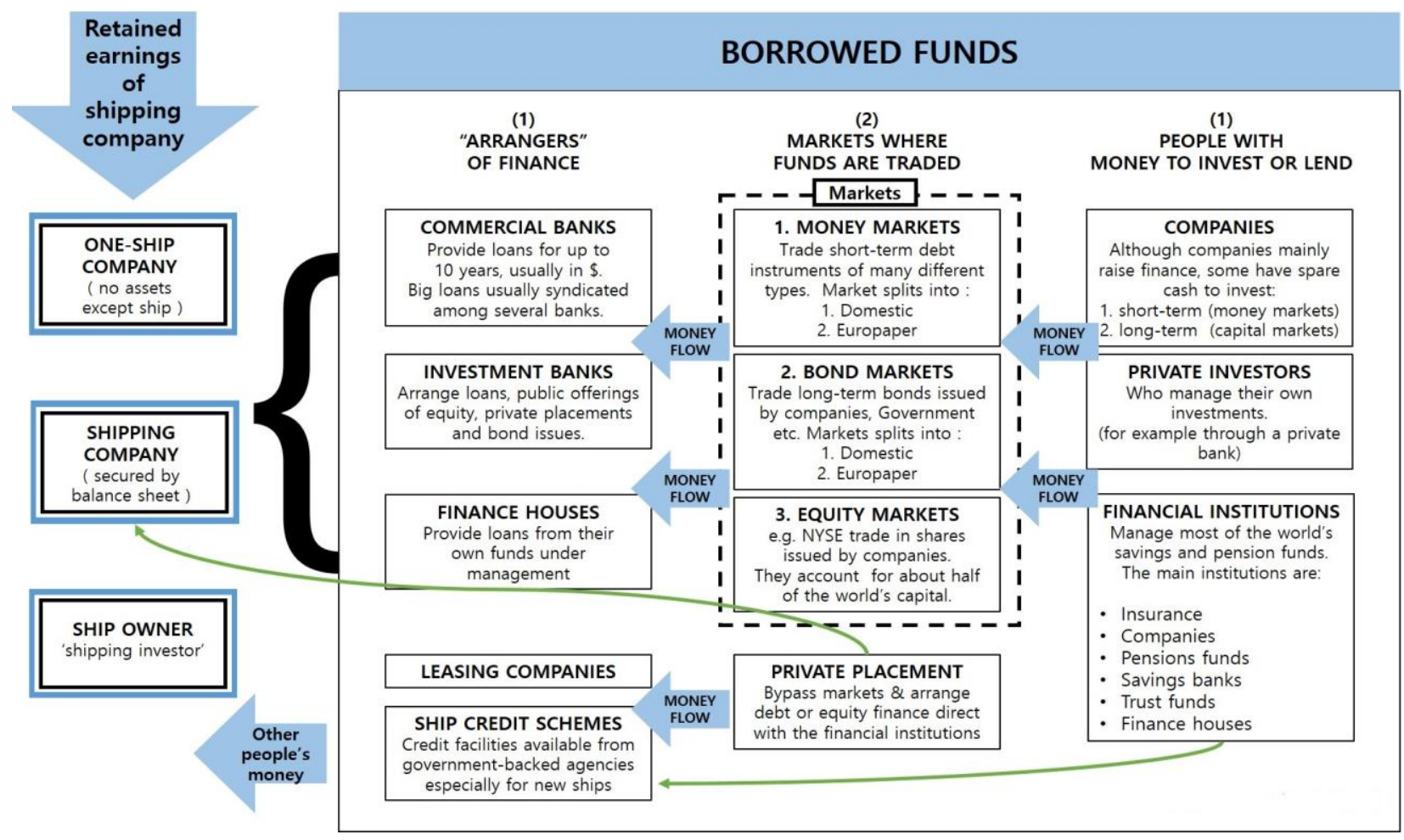

Figure 1. Sources of shipping finance (Source: Stopford (2009))

The flow chart displayed in Figure 1 shows how the different parts of the system interact. The third column on the right shows the source for investment funds, the middle column, column 2, displays markets where funds are traded, while the far left column, column 1, identifies the intermediaries and risk-takers in providing business capital, with access to the pool of funds listed in columns 2 and 3. The predominant funding option in shipping finance is a bank loan. Commercial and investment banks provide loans either by borrowed capital, such as private loans, or deposit or security issuance. Due to equity regulation and funding limitations, predominantly multiple banks provide loans as syndicates. Financial markets provide an alternative source for funding. Each markets in column 2 trades in different types of securities. First, money markets offer short-term loans. This market consists of a loose network of banks and dealers linked by telephone, e-mail, and computers, dealing in short-term debt securities, including bankers' acceptances, commercial paper, negotiable certificates of deposit, and Treasury bills featuring a maturity of a maximum of 1 year. Second, bond markets trades in interest bearing securities with a redemption date of more than a year, and often between 10-15 years. Companies issue bonds or debentures through dealers. To make debentures tradable, the issuing company must acquire a high credit rating from well-known credit rating agencies such S\&P and Moody's. Third, equity markets trade in equities. This allows companies to raise capital through public offerings on the stock market. Companies must abide by SEC regulations in the United States, and entice potential investors to purchase stock. The final option is to either use internal capital or obtain funding from individuals or organizational investors seeking to invest in the shipping industry.

Stopford (2009) has classified 14 methods of shipping finance, as displayed in Table 1, including private funds, bank loans, capital markets, and special purpose companies (SPCs). Private funds include cash generated by the business, and loans or equity from friends, relatives or venture capitalists. It is often the only source available for start-up businesses. Most shipping businesses still finance part of their activities from this internally generated equity, and family ownership remains as a common form of finance in Greece, Norway, and Hong Kong. Second, bank loans are a major source of finance for ship-owners and shipping companies. Bank loans are one of the most commonly used funding options due to their relatively low expense and simple structure compared with initial public offerings (IPO) and special purpose vehicle (SPV). There are five types of bank financing listed in Table 1: mortgage loans secured against the ship; corporate loans secured against the company balance sheet; shipyard credit; and mezzanine finance as well as private placement. The market for commercial bank loans is very competitive, and also flexible due to loans being easily refinanced when required. Mortgage-backed loans are term-loans featuring the ship as collateral. Large loans are made by syndicates where multiple banks collaborate with each other. Corporate loan is based on the company balance sheet and is mostly applied as term loans or revolving credit. Shipyard credit is implemented to support domestic orders of shipbuilding companies, including the guarantee or assurance by the government or public organization. Mezzanine finance is the funding option that is relevant for loans, stock, or both. For example, bond with warrant. Private placement positions stock or bond directly with one or more institutional investors without listing or under regulation from the SEC. 
Table 1. Fourteen options for financing ship (Source: Stopford (2009))

\begin{tabular}{|c|c|c|}
\hline Method of raising funds & Structure of finance & Features of structures \\
\hline \multirow{2}{*}{ 1. Private funds } & Own funds & $\begin{array}{l}\text { Equity finance provided by owner or private investors in return for } \\
\text { shares in a privately held company. }\end{array}$ \\
\hline & Private investment & $\begin{array}{l}\text { Equity or loan arranged privately with family, colleagues, high-net } \\
\text { worth individuals. }\end{array}$ \\
\hline \multirow{5}{*}{ 2. Banks finance } & Mortgage-backed loan & $\begin{array}{l}\text { Term loan provided by bank, secured against mortgage on ship(s). } \\
\text { Large loan may be syndicated between several banks. }\end{array}$ \\
\hline & Corporate loan & $\begin{array}{l}\text { Loan secured against the company's balance sheet. E.g. term loan or } \\
\text { revolving credit (assured credit line) }\end{array}$ \\
\hline & Shipyard credit & $\begin{array}{l}\text { Loan provided or guaranteed by government or agency to assist } \\
\text { domestic shipyards in obtaining orders. }\end{array}$ \\
\hline & Meazzanine finance & $\begin{array}{l}\text { Finance containing elements of both debt and equity. E.g. debt with } \\
\text { an equity warrant. }\end{array}$ \\
\hline & Private placement & $\begin{array}{l}\text { Sale of equity or corporate debt to one or several investment } \\
\text { institutions. Avoid lengthy public offering process. }\end{array}$ \\
\hline \multirow{2}{*}{ 3. Capital markets } & Public offering & $\begin{array}{l}\text { Finance containing elements of both debt and equity. E.g. debt with } \\
\text { an equity warrant. }\end{array}$ \\
\hline & Bond issue & $\begin{array}{l}\text { Sale of equity or corporate debt to one or several investment } \\
\text { institutions. Avoids lengthy public offering process. }\end{array}$ \\
\hline \multirow{5}{*}{ 4. Special purpose vehicles } & $\begin{array}{l}\text { Special purpose company or } \\
\text { SPAC }\end{array}$ & $\begin{array}{l}\text { Shares in a special purpose company and sold privately by } \\
\text { individuals or may be listed on a stock exchange. }\end{array}$ \\
\hline & Limited partnership & $\begin{array}{l}\text { Limited liability partnership set up as a vehicle for financing ships. } \\
\text { Equity provided by private investors and debt by bank, e.g. K/S and } \\
\text { German KGs. }\end{array}$ \\
\hline & Finance lease & $\begin{array}{l}\text { Long-term tax-efficient finance based on sale of ship to company } \\
\text { which benefits from tax allowances and leases the ship back to user. }\end{array}$ \\
\hline & Securitization & $\begin{array}{l}\text { Short-term lease, generally less than } 7 \text { years, which does not have to } \\
\text { be shown on the lessee's balance sheet. }\end{array}$ \\
\hline & Bond issue & $\begin{array}{l}\text { Financing structure designed to separate the assets from the } \\
\text { company management. }\end{array}$ \\
\hline
\end{tabular}

Third, capital markets provide shipping companies with equity through an initial public offering (IPO) of shares, or debt by issuing bonds. This works best for larger shipping companies, especially those with over $\$ 1$ billion in net worth. The last option is to use a special purpose vehicle (SPV) in order to own ships and raise capital financing. This technique is often used when shipping companies want the use of ships without having them on the balance sheet, or when tax allowances are available.

These financing options listed so far have been useful to shipping industry. From now on, the funding methods used in shipbuilding will be explained. In fact, the shipbuilding industry uses all the funding methods used by shipping industry. Furthermore, because of the nature of the shipbuilding industry, three additional financing methods becomes available. Now the additional methods are described below.

The first is shipbuilding credit. Most countries offer shipbuilding credit to domestic and foreign owners. Terms of export credit are agreed under the OECD Understanding on Export Credit, and currently set at 80 per cent advance of 8.5 years at 8 per cent interest per annum. The funds are provided either by a government or a commercial bank with the government guarantee and subsidy covering the difference between the pricing of the loan and the rate at which they borrow from the local money market. Shipbuilding finance can be made in two stages: pre-delivery of ship, and post-delivery of ship. Post-delivery finance is generally drawn on delivery of the vessel. The funding may be obtained from three sources include a Shipyard Credit Scheme, Commercial Bank Credit, or leasing. The lender risk is smaller compared to pre-delivery loans as the ship is secured. Conversely, as the result of stage payments made before the ship is completed, there is no ship to act as collateral if the shipyard goes bankrupt. Thus the lender needs some other form of collateral, predominantly a refund guarantee (known as $R G)^{c}$ is issued by the shipyard's bank.

The second option available is project finance $(\mathrm{PF})$. Project finance is the long-term financing of infrastructure and industrial projects based upon the projected cash flows of the project rather than the balance sheets of its sponsors. Usually, a project financing structure involves a number of equity investors as sponsors, syndicated banks, or other lending institutions that provide loans collectively. Thus, project financing is often more complicated than alternative financing methods ${ }^{\mathrm{d}}$. Traditionally, project financing has been used in the extractive mining, transportation, and

\footnotetext{
${ }^{c}$ Advance refund guarantee is a letter of assurance stipulating that the advance to be received by the shipbuilding companies is paid by the financial company if shipbuilding company receiving the advance from the ship owner fails to construct the ship in the pre-determined period.

d A complex project finance structure may incorporate corporate finance, securitization, options (derivatives), insurance provisions as well as other types of collateral enhancement to mitigate risk.
} 
telecommunications industries as well as in shipbuilding. Risk identification and allocation is a key component of project finance. A project may be subject to a number of technical, environmental, economic and political risks, particularly in developing countries and emerging markets. Financial institutions and project sponsors may conclude that the risks inherent in project development and operation are unacceptable. Several long-term contracts such as construction, supply, off-take and concession agreements, along with a variety of joint-ownership structures are used to align incentives and deter opportunistic behavior by parties involved in the project. Riskier or more expensive projects may require limited recourse financing secured by a surety from sponsors.

The third option is the rescheduling of repayment. Default may occur in shipping finance due to the rapid deterioration of the market or difficulty in repayment with pre-determined profit. In these cases, the following options are available: First of all, it is possible for rescheduling repayment. The shipping market deteriorating rapidly makes it difficult to repay principal with cash flow. Rescheduling principal repayment becomes an attractive option if the recession is not anticipated to last long, and if there is no significant problem with the credit rating of the business holder (guarantor). This is the most desirable option from the perspective of financial institutions, and it is important to continue business for the ship-owner through debt settlement. Secondly, negotiation is required among creditors in the case of default. It is common for the lead bank with the highest amount invested to initiate negotiation. If there is mortgage involved, it is feasible to use operating profit for collecting principal, and to collect loan amounts through sales when the market recovers.

Now, let us review the current global shipping finance market in Table 2. Global shipping finance as of November, 2014, was approximately 392 billion dollars. DnB was the largest bank in shipping finance, followed by HSH Nordbank-only core and Bank of China.

Table 2. Ship finance based on interim data up to November 2015 (billion) (Source: Petrofin Research)

\begin{tabular}{lc|lc}
\hline Bank & Volume & Bank & Volume \\
\hline DnB & 28.30 & Bremer Landesbank & 8.23 \\
HSH Nordbank-only core & 21.98 & UtscheShipping-Deutsche Bank & 8.14 \\
Bank of China & 20.00 & ING & 7.50 \\
Kfw & 19.80 & Danish Ship Finance & 6.59 \\
Nordea & 18.30 & Unicredit & 6.20 \\
ICBC & 17.50 & Standard and Chartererd & 5.50 \\
Korea Exim & 17.00 & Development Bank of Singapore & 5.00 \\
Commerzbank & 16.00 & Santander & 5.00 \\
DVB & 15.50 & SEB & 4.50 \\
BTMU & 15.00 & Danske Bank/Fokus Bank & 4.00 \\
RBS & 14.22 & Japan Bank for International Cooperation & 4.00 \\
China Exim & 14.00 & Piraeus Bank & 3.90 \\
Bord LB & 13.80 & National Bank of Greece & 3.20 \\
BNP Paribas & 12.80 & Lloyds Banking Group & 2.50 \\
Credit Suisse & 12.80 & NIBC & 2.50 \\
HSBC & 10.00 & Commomwealth Bank of Australia & 2.50 \\
Credit Agricole & 10.00 & Alpha Bank & 2.44 \\
SMBC & 10.00 & Societe General & 2.00 \\
ABN Amro & 8.46 & Deka & 2.00 \\
Citibank & 8.30 & CIT Group & 2.00 \\
\hline
\end{tabular}

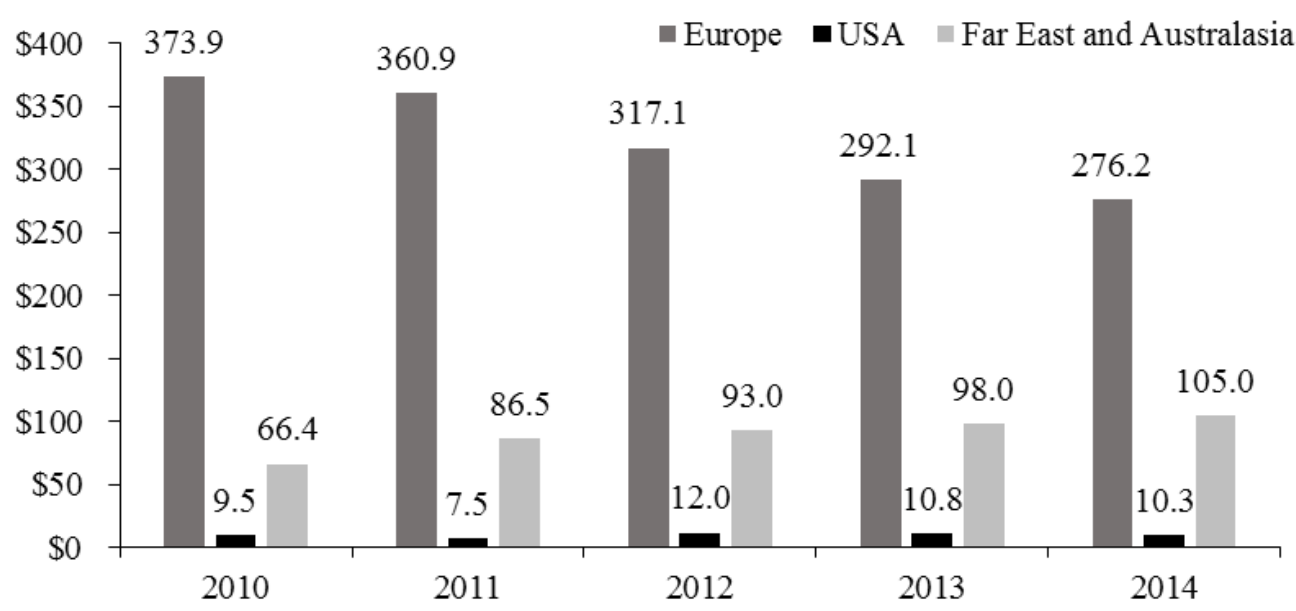

Figure 2. Top 40 banks in terms of geographical position - 2010 to 2015 (billion) 
Figure 2 shows that shipping finance of the top 40 companies in Europe significantly decreased from 373.8 billion dollars in 2010 to 247.9 dollars in 2015. Conversely, investment in shipping finance in East Asia and Australia nearly doubled from 66.4 billion dollars in 2010 to 129 billion dollars in 2015. Therefore, it can be understood that the decreased capital used in shipping finance from European banks was partially offset by increases in Asian countries, including China and Korea.

Table 3 represents funding options in global shipping finance. As examined, loan amount from European banks was significantly reduced following the European financial crisis in 2011. The proportion of bank loans used in funding was significantly reduced from $85.6 \%$ in 2008 to $59.4 \%$ in 2013 . Conversely, follow-on financing significantly increased from $4 \%$ in 2008 to $17.1 \%$ in 2013. Reductions in bank loans have negatively impacted the shipping and shipbuilding industries, resulting in the poor performance of shipping and shipbuilding industries in Korea. Shipping finance in Korea, including the shipping and shipbuilding industries, has mostly been implemented by government banks, including KDB and KEXIM in Table 4. There is a low proportion of investment originating from commercial banks ${ }^{\mathrm{e}}$. The relatively small amount of loans by commercial banks in Korea, and the concentration within several banks, occurs as a result of most shipping finance is involved in project finance, as well as the difficulty in collecting bonds in case of default from syndicate loans. Due to the aforementioned reasons, the proportion of government bank financing is $74.8 \%$ in the shipbuilding industry and $67.8 \%$ in the shipping industry. Therefore, it is clear that government-run banks are integral participants in this market.

Table 3. Trends of ship finance sources (Source: Dealogic)

\begin{tabular}{lll}
\hline & 2008 & 2009 \\
\hline Corporate bond & $4.0 \%$ & $17.1 \%$ \\
Bank loan & $85.6 \%$ & $59.4 \%$ \\
Follow-on & $4.3 \%$ & $6.3 \%$ \\
Equity & $0.0 \%$ & $3.3 \%$ \\
Convertible bond & $0.3 \%$ & $1.3 \%$ \\
IPO & $0.0 \%$ & $2.4 \%$ \\
Private placement & $0.9 \%$ & $6.8 \%$ \\
Leasing & $5.0 \%$ & $3.5 \%$ \\
\hline
\end{tabular}

Note: $0.0 \%$ implies that the corresponding value was less than $0.05 \%$.

Table 4. Exposure of Korean banks about 4 shipbuildings and 2 shippings (2016.5) (unit: billion won)

\begin{tabular}{|c|c|c|c|c|c|c|}
\hline & \multicolumn{3}{|c|}{4 shipbuildings } & \multicolumn{3}{|c|}{2 shipping } \\
\hline & Loan & etc. & Sum & Loan & etc. & Sum \\
\hline Kookmim & 574 & 1584 & 2158 & 114.6 & 0 & 114.6 \\
\hline Shinhan & 231 & 3093 & 3324 & 10 & 0 & 10 \\
\hline Woori & 941 & 3724 & 4665 & 155.5 & 0 & 155.5 \\
\hline KEBHana & 1598 & 2593 & 4191 & 139.7 & 12.7 & 152.4 \\
\hline IBK & 394 & 1357 & 1751 & 0 & 0 & 0 \\
\hline other commercial & 42 & 143 & 185 & 0 & 0 & 0 \\
\hline DGB & 50 & 0 & 50 & 0 & 0 & 0 \\
\hline BNK & 0 & 23 & 23 & 8.2 & 0 & 8.2 \\
\hline Kyongnam & 30 & 83 & 113 & 0 & 0 & 0 \\
\hline Jeonbuk & 50 & 28 & 78 & 0 & 0 & 0 \\
\hline Gwangju & 0 & 0 & 0 & 0 & 0 & 0 \\
\hline Foreign & 1294 & 2312 & 3606 & 24.8 & 0 & 24.8 \\
\hline $\mathrm{KDB}$ & 5483 & 4438 & 9921 & 951.6 & 300.2 & 1251.8 \\
\hline Suhyup & 0 & 7 & 7 & 0.5 & 0 & 0.5 \\
\hline $\mathrm{NH}$ & 405 & 3723 & 4128 & 151.9 & 0 & 151.9 \\
\hline EXIM & 5644 & 21629 & 27273 & 50 & 0 & 50 \\
\hline Sum & 16736 & 44737 & 61473 & 1606.8 & 312.9 & 1919.7 \\
\hline
\end{tabular}

Note: Top 4 shipbuilding companies include Daewoo shipbuilding, Samsung heavy industries, Hyundai heavy industries, and Hyundai mipo. two shipping companies include Hanjin shipping and Hyundai shipping. Etc. includes the loan guarantees.

It is evident that multiple financial institutions participate as syndicates in shipping finance. In addition, it is the norm to include established financial institutions (or government-run banks) in order to raise the possibility of collection in bankruptcy. Section 3 examines theoretical phenomena based on incomplete contract theory between principal-agent.

We view the ship-owner who applies for shipping finance as the agent, and banks who participate in syndicate loans

\footnotetext{
e Among the 1,806.4 trillion Won of loan balance in the entire commercial banks as of 2014, total balance of shipping finance is 3.7 trillion Won. This constitutes only $0.2 \%$ in shipping finance of the total assets (a Member of Congress, Junghoon Kim (2015)).
} 
as the principal. Two issues arise besides moral hazard and non-verifiability in traditional incomplete contract theory. Firstly, there exists the issue of an individual's interest among creditors for the collection of bonds in case of default. The higher the number of creditors, the more difficult it is to reach consensus regarding collection in bankruptcy Secondly, there is the issue regarding monitoring of exploitation by the borrower, the ship owner, in bankruptcy. It is known that the higher the number of creditors creates more advantage to prevent private benefit accruing to ship-owners. Considering the two conflicting forces resulting from the increase in creditor members, the crucial decision is how to better monitor, in conjunction with minimizing inefficiency, coordination failure in bankruptcy. In summary, determining the optimal number of creditors requires consideration of the trade-offs between these two issues when configuring syndicate loans. Section 3 suggests a model for determining the optimal number of creditors in the syndicate for shipping finance based on Bolton and Scharfstein (1996).

\section{Theoretical model}

Bolton and Scharfstein (1996) developed a model regarding the optimal number of creditors within the incomplete contracts framework. Their model shows that the number of creditors will affect the bargaining processes and sale value determination for collection and recovery processes in the event of default. Particularly, they identify the tradeoff effects between liquidation value and the monitoring of private extortion by managers using the Nash bargaining process and Shapley value analysis. We extend their model by way of generalizing the number of creditors and then apply it to shipping finance. Bolton and Scharfstein analyzed how the solution of Nash bargaining between limited number of fund provider and the borrower manager changes when the number of the fund provider increases from one to two. Our study, on the other hand, differs in that it generalizes the analysis of liquidation value and monitoring effects in the case of more than two fund providers. Tirol's model was also adopted because it is necessary for the owner of ship to invest his own equity to a certain extent in the case of ship financing, In addition to the incomplete contract features, we also considers the manager's moral hazard. This is partly due to the recent controversy in Korea regarding the distressed Daewoo Shipbuilding case.

\subsection{Basic set-up}

We consider a two-period shipbuilding project that requires an outlay of $I$ at an initial period 0 for the purchase of physical assets. The shipbuilding project is administered by an entrepreneur (or manager) who has wealth of $A$. Thus, the entrepreneur borrows $I-A$ from multiple creditors in order to finance the shipbuilding project of value $I$. The project operates for two periods. In period 1 , the project yields a random cash flow of either x with probability $P_{i}$, or zero with probability $1-P_{i}$, where $i \in\{H, L\} . H$ and $L$ represent high-level effort of the manager and low-level effort of the manager, respectively. In this way, we consider moral hazard of the entrepreneur. The project produces another cash flow in period 2, which depends on how assets are deployed in period 1. If the manager is able to continue to manage assets in period 2, its cash flow becomes $C$, which is the highest possible cash flow. Otherwise, when nonpayment to the lender (or creditor) occurs in period 1 , the project is liquidated with a probability of $q_{0}$ in period 2 at the value of $\beta C$, where $\beta \leq 1$. Thus, liquidation is inefficient. The nonpayment in period 1 may occur in the following two cases: Firstly, the project itself fails with the probability of $1-P_{i}$. Secondly, the entrepreneur strategically claims that the project fails in order to receive private benefit (i.e. $S$ ), even when the project succeeds. It is so-called non-verifiable income property, as frequently used in debt contract theory.

We describe the moral hazard possibility and the non-verifiable income property in orders. First, we assume that the manager faces a tradeoff between ethical behaving and misbehaving once the financing has been secured. Misbehaving enables the realization of private benefit $B$ to the manager, but it reduces the probability of success from $P_{\mathrm{H}}$ to $P_{\mathrm{L}}$, where $P_{\mathrm{L}}=P_{\mathrm{H}}-\Delta P<P_{\mathrm{H}}$. As a result of receiving $R_{\mathrm{x}}$ as remuneration once cash flow $x$ is generated in success while 0 in failure, the entrepreneur therefore behaves if the following "incentive compatibility constraint" is satisfied:

$$
P_{\mathrm{H}} R_{\mathrm{x}} \geq P_{\mathrm{L}} R_{\mathrm{x}}+B \text { or } \triangle P R_{\mathrm{x}} \geq B
$$

From this incentive compatibility constraint of moral hazard, we can infer that the highest income in the case of success to the entrepreneur without jeopardizing incentives is:

Lemma 1. $R_{x}=\frac{B}{\Delta P}$

Lemma 1 implies that the manager's remuneration in period 1 becomes greater when his private benefit $B$ in the case of misbehaving becomes larger, or if increment in success probability by behaving relative to misbehaving is reduced. Due to non-verifiability of income $\mathrm{x}$, we need another incentive constraint that ensures that the manager truthfully reports 
the actual cash flow of $x$. We can write this incentive constraint as:

$R_{\mathrm{x}}+\left(1-q_{\mathrm{x}}\right) \mathrm{C} \geq x+q_{0} S+\left(1-q_{0}\right) C$

The contract specifies that if the manager truthfully reports cash flow as $\mathrm{x}$, investors (lenders) have the right to liquidate assets with probability $q_{\mathrm{x}}$. However if the manager report 0 even in that case and does not make payment to investors, investors have the right to liquidate the assets with probability $q_{0} . \mathrm{S}$ denotes the utility the manager receives by falsely reporting that cash flow is zero, and thus the creditor is entitled to liquidate the asset. Note that investors cannot induce the manager to pay in period 2 because there are no remaining assets to liquidate in the last period. Given this contract, the firm(shipbuilder)'s expected payoff is:

$P_{\mathrm{H}}\left\{R_{\mathrm{x}}+\left(1-q_{\mathrm{x}}\right) C\right\}+\left(1-P_{\mathrm{H}}\right)\left\{R_{0}+\left(1-q_{0}\right) C\right\}$

The lenders' (creditors) expected profit is:

$P_{\mathrm{H}}\left(x-R_{\mathrm{x}}+q_{\mathrm{x}} \beta C\right)+\left(1-P_{\mathrm{H}}\right)\left(-R_{0}+q_{0} \beta C\right) \geq I-A$

where $\beta C$ refers to the liquidation value of the assets for lenders when they decide to liquidate. Although creditors derive zero direct value from owning the assets, they can still sell the assets and receive proceeds as $\beta C$. Reflecting early termination of the project and the consequent inefficiency, $\beta$ is assumed to be less than or equal to 1 .

The contract maximizes the shipbuilding firm's expected payoff (2) subject to the two previous incentive constraints and constraint (3) that the creditor's profits are nonnegative. It is straightforward to establish two preliminary results: (i) $q_{\mathrm{x}}=0$. This means that it is not optimal to liquidate when the firm makes the payment $x-R_{\mathrm{x}}$ to lenders and (ii) $R_{0}=0$. This means no remuneration to the manger if the project fails at period 1. Firstly, setting $q_{\mathrm{x}}=0$ is optimal because it maximizes the surplus from the contract while providing the manager enough incentive to pay out to creditors. If $q_{\mathrm{x}}$ were strictly positive, then the creditor could be made no worse off by reducing $q_{\mathrm{x}}$ by some infinitesimal amount, $\varepsilon$, and increasing $x-R_{\mathrm{x}}$ by $\varepsilon \beta C$. Such an arrangement would increase the manager's expected payoff by $\varepsilon(1-\beta) C$ in equation (2) while relaxing the incentive constraint (i.e., $\mathrm{IC}_{2}$ ). $R_{0}=0$ is better for the firm's profit maximization and provides the manager with incentives. The only alternative is to set $R_{0}>0$, that is, pay the manager something even in bad state. It would be better to reduce $R_{0}$ while consequently reducing $q_{0}$ in order to make the lender no worse off. Then, as before, considering that liquidation is inefficient, this arrangement will increase the shipbuilder firm's expected payoff. Thus equation (2) and (3) becomes:

$P_{\mathrm{H}}\left(R_{\mathrm{x}}+C\right)+\left(1-P_{\mathrm{H}}\right)\left(1-q_{0}\right) C$

$P_{\mathrm{H}}\left(x-R_{\mathrm{x}}\right)+\left(1-P_{\mathrm{H}}\right) q_{0} \beta C \geq I-A$

Furthermore, with the consideration of lemma 1, the incentive constraint $\left(\mathrm{IC}_{2}\right)$ reduces to:

Lemma 2. $x-R_{x}=x-\frac{B}{\Delta P} \geq q_{0}(C-S)$

Equation (4) must be binding at an optimal level; otherwise it would become optimal by increasing $\mathrm{q}_{0}$ until the equation binds and the lender increases his remuneration at period 1 by $x-B / \Delta P$ while ensuring the manager has no incentive to misreport cash flow of $x$. Substituting equation (4) into the lenders' expected profit constraint, equation (3-1) and then assuming that the lending market is competitive implies that:

$P_{\mathrm{H}} q_{0}(C-S)+\left(1-P_{\mathrm{H}}\right) q_{0} \beta C=I-A$

Using equation (5), we can rewrite the manager's expected payoff, equation (2) as:

$P_{\mathrm{H}} x+C-(I-A)-\left(1-P_{\mathrm{H}}\right) q_{0} C(1-\beta)$

The first three terms in equation (6) represent the net present value of the project in success without liquidation. The last term is the expected efficiency loss from contractual incompleteness; it is the probability of liquidation, $q_{0}$, times the loss in value from liquidation, $C(1-\beta)$. Given that the manager's object function is clearly decreasing in $q_{0}$ while the lenders' profits are increasing in $q_{0}$, we derive the following proposition 1: 
Proposition 1. The optimal solution is to set $\mathrm{q}_{0}$ in equation (5) equal to its lowest possible level as:

$$
q_{0}=\frac{I-A}{P_{H}(C-S)+\left(1-P_{H}\right) \beta C}
$$

To make equation (7) valid, $I-A$ should be less than the maximum feasible gross profit to creditors, $P_{\mathrm{H}}(C-S)+(1-$ $\left.P_{\mathrm{H}}\right) \beta C$ because $q_{0}$, a liquidation probability in the bad state should be no greater than one. Also $q_{0}$ should be greater than 0 in order to incentivize the manager to not divert cash during the good state. Note that this arrangement is less likely to be feasible if (1) the financing amount from outside lenders, $I-A$, is large relative to the maximum amount that can be promised to the investors (or creditors), or if (2) project has either low continuation value (low $C$ ), low liquidation value $(\beta C)$, or high managerial benefit in the case of liquidation (high $S$ ). Regarding such projects, if financed, the probability of liquidation would become higher.

Our optimal contract has three features. First, liquidation occurs when the firm's performance in period 1 is poor. This is not only due to poor early performance signaling poor future performance, but also because the threat of liquidation serves as a way of inducing the manager to pay out cash to lenders instead of diverting it to himself when cash flow is $x$. In equilibrium, thus, the positive probability of liquidation is inevitable whenever the contract is non-verifiable. If the manager were to keep the first period cash flow, the creditor would liquidate the assets with probability $q_{0}$, which generates a second period payoff of $S(<C)$ to the manager. When the first period cash flow is in fact $\mathrm{x}$, the manager would prefer to pay $q_{0}(C-S)$ to lenders than to keep the cash and forfeit $q_{0}(C-S)$. Unfortunately, however, if first period cash flow turns out to be zero, the manager has no choice but to liquidate assets with probability $q_{0}$ since he lacks cash to pay the amount $q_{0}(C-S)$.

Second, the liquidation of assets by lenders is inefficient as $\beta$ is less than one. If the project continues, then the second-period cash flow will be $C$ regardless of the relation of $\mathrm{x}$ in the first period. However, the cash flow is reduced to $\beta C$ when the lender liquidates. Thirdly, payment to the manager in period 1 should be at least $B / \Delta P$ in order to prevent moral hazard of the manager.

\subsection{Multiple lenders case}

We consider two different effects on the liquidation probability in the bad state, $q_{0}$, when the number of creditors increases. First the increasing number of creditors will reduce $\mathrm{q}_{0}$ in equation (7) because $S$, the manager's private benefit, is lowered by enhanced monitoring power from the creditor syndicate. Note that $S$ is the private benefit of the manager when the lender is entitled to liquidate the asset if cash flow is $x$ but. Secondly, the increased number of creditors will increase $q_{0}$ in equation (7), as it reduces the liquidation value $\beta C$. This is because coordination failure regarding liquidation is more likely to happen as the number of lenders is increased. Smith and Warner (1979) and Holmstrom (1982) suggest that the borrower's costs for renegotiation increase as the number of creditors becomes larger. This is because coordination among many lenders becomes more difficult. On the contrary, if the loan syndicate is comprised of only one lender, the costs of renegotiation would be extremely small. Our view is slightly different from Bolton and Scharfstein (1996). They find that $S$ and liquidation value decrease when the number of lenders increases from different reason. Bolton and Scharfstein (1996) predict that bargaining outcomes for individual participants including manager become lower as more participants are involved. That is how they rationalize the shrinking $\mathrm{S}$ of the manger, which we do not agree. On the contrary, Bris and Welch (2004) empirically studied the optimal concentration (or distribution) of lenders under the consideration of free-riding problem among lenders. They conclude that a concentration of creditors is better at negating problems with free-riding. However, they found that social waste in debt collection expenditures becomes larger when creditors are concentrated, and that collection activity is purely distributive. Our argument follows their view of useless distributive collection activity by allowing the reduced $\beta C$ when the number of creditors becomes larger.

Now we introduce notation for the more-than-one creditor case in $S, \beta$ and $q_{0}$. To emphasize the dependence of these three variables on the number of creditors, we will rewrite as $S(n), \beta(n)$ and $q_{0}(n)$ as the following:

$$
\begin{aligned}
& S(n)=\left(1-\frac{n}{N}\right) C \text { where } n \in\{1,2, \ldots, N\} . \text { Thus } S^{\prime}(n)<0, \\
& \beta(n) C=\alpha\left(1-\frac{n}{N}\right) C \text { where } n \in\{1,2, \ldots, N\} \text { and } \beta \leq 1 . \text { Thus } \beta^{\prime}(n)<0
\end{aligned}
$$

Once we substitute the above $S(n)$ and $\beta(n)$ into equation (7), we can rewrite the fourth term of equation (6), (1 $\left.P_{\mathrm{H}}\right) q_{0} C(1-\beta)$ as the following:

Considering that now $q_{0}(n)$ is: 
$\frac{I-A}{P_{H} \frac{n}{N}+\left(1-P_{H}\right) \alpha\left(1-\frac{n}{N}\right)}$

$\left(1-P_{\mathrm{H}}\right) q_{0} C(1-\beta)$ becomes:

$$
\left(1-P_{H}\right)(I-A) \frac{(1-\beta) C}{P_{H}(C-S)+\left(1-P_{H}\right) \beta C}
$$

Furthermore, it can be expressed as:

$$
(I-A) \frac{(1-\beta) \frac{n}{N}}{P_{H} \frac{n}{N}+\left(1-P_{H}\right) \alpha\left(1-\frac{n}{N}\right)}
$$

Differentiating equation (10) with respect to $n$ derives:

$$
\frac{d\left[q_{0}(n)\{1-\beta(n)\}\right]}{d n}=\frac{\frac{\alpha}{N}\left\{P_{H} \frac{n}{N}+\left(1-P_{H}\right) \alpha\left(1-\frac{n}{N}\right)\right\}-\left\{1-\alpha\left(1-\frac{n}{N}\right)\right\}\left\{\frac{P_{H}-\left(1-P_{H}\right) \alpha}{N}\right\}}{\left\{P_{H} \frac{n}{N}+\left(1-P_{H}\right) \alpha\left(1-\frac{n}{N}\right)\right\}^{2}}>0
$$

Rearranging numerator term in equation (11) gives:

$$
\frac{1}{N}\left[a^{2}\left(1-P_{H}\right)-(1-\alpha)\left\{P_{H}-\left(1-P_{H}\right) \alpha\right\}\right]
$$

From equation (12), when $\alpha=1$, the numerator becomes $1-P_{\mathrm{H}}>0$. On the contrary, when $\alpha=0$, the numerator becomes $-P_{\mathrm{H}}<0$. Thus, we can see that base on equation (12), the derivative value of $d\left[q_{0}(n)\{1-\beta(n)\}\right] / d n$ in equation (11) is increasing in $\alpha . \alpha$ implies the magnitude of coordination failure inefficiency on liquidation value, $\beta(n)$, relative to $S(n)$. Note that $S(n)$ represents the private benefit of the manger. The positive value of equation (11) means that the larger number of creditor (i.e., bigger $\mathrm{n}$ ) is detrimental to a firm's profit and vice versa. It can be understood that $d^{2}$ $\left[q_{0}(n)\{1-\beta(n)\}\right] / d n d \alpha$ is positive if $\alpha>P_{\mathrm{H}}$. Here, larger $\alpha$ represents the magnitude of coordination failure inefficiency dominates that of the private benefit exploitation by the manager. Now we can conclude that the number of optimal creditors, $\mathrm{n}$, is likely to decrease if the inefficiency in liquidation value dominates the enhanced monitoring power of the creditor syndicate. Otherwise, vice versa.

Proposition 2. Depending upon the size of $\alpha$, cost term to the manager, i.e., $\left(1-P_{\mathrm{H}}\right) q_{0} C(1-\beta)$ could either increase or decrease. Larger $\alpha$ implies that the increased number of creditors is detrimental to the firm due to the effect of coordination failure being greater than that of the enhanced monitoring benefit.

\section{Conclusion}

Restructuring shipping and shipbuilding companies in the midst of rapidly shrinking global demand has become a prominent issue in Korea. Many reasons explaining the troubled shipping industry have been suggested, including excessive investment, falling freight charges, and the cost burden of expensive ship chartering contracts. However, a fundamental reason is the pressure of loan repayment resulting from high debt ratio. Ship financing is generally regarded as a specialist business, or 'exotic' finance area. Loan syndication surges as the most viable and preferred option. Furthermore, the number of members in syndicates increases as the size of ships increase.

Under such circumstances, the aim of this paper is to explain the role of finance in the shipping and shipbuilding industries and determine the optimal number of creditors in shipping finance syndicates based on Bolton and Scharfstein (1996). Two issues arise in addition to moral hazard and non-verifiability. First is the coordination issue among many creditors for collection of bonds in the case of default. The higher the number of creditors, the greater the difficulty in reaching consensus regarding collection among members in the case of bankruptcy. Second is enhancing 
the monitoring of private benefit exploitation by ship owner in default. Considering the two conflicting forces result from increasing creditor membership, the crucial decision is how to better monitor and minimize inefficiency from coordination failure in bankruptcy. We identify the optimal number of creditors by considering the trade-offs between these two issues. More creditors are preferred when the monitoring effect dominates, and otherwise less creditors would be preferred.

A follow up study may explore to endogenize the decision on the entrepreneur's equity amount. In addition to the effect of creditors' number on monitoring and debt collection, it is also possible to derive optimal number of creditors according to the degree of development of secondary market and the amount of information disclosure, in addition to the number of participants. In addition, it is interesting to further investigate not only Korea but also developed countries where ship financing has developed.

\section{Acknowledgement}

This work was supported by INHA University Research Grant.

\section{References}

Bris, A., Welch, I., 2005. The optimal concentration of creditors. Journal of Finance 60, 2193-2212.

Bolton, P., Scharfstein, D.S., 1996. Optimal debt structure and the number of creditors, Journal of Political Economy 104, 1-25.

Duru, O., 2013. Irrational exuberance, overconfidence and short-termism: knowledge-to-action asymmetry in shipping asset management. The Asian Journal of Shipping and Logistics 29, 43-58.

Holmstrom, B., 1982. Moral hazard in teams. The Bell Journals of Economics 13, 324-340.

Kim, J.W., 2016. Sector update banks. Samsung Securities, Republic of Korea.

Kim, J.W., 2015. Current shipping finance in Korea. KDB Bank, Republic of Korea.

Morris, S., Shin, H.S., 2004. Coordination risk and the price of debt. European Economic Review 48, 133-153.

Petropoulos, T., 2015. Trends in global finance in the current market. Proceedings of 1st Naftemporiki Shipping Forum, Vouliagmeni, Greek.

Smith, C., Warner, J., 1979. On financial contracting: an analysis of bond covenants. Journal of Financial Economics 7, $117-161$.

Stopford, M., 2009. Maritime Economics 3rd edn. Routledge: Taylor \& Francis Group, London and New York.

Tirole, J., 2006. The Theory of Corporate Finance. Princeton University Press, New Jersey. 